\title{
Vertebroplasty: Expectation or Evidence-Based Interventional Radiology?
}

$T^{1}$ he review of the latest data concerning vertebroplasty and kyphoplasty for osteoporotic vertebral fractures seemed a desperate attempt to cleanse the unconscionable. ${ }^{1}$

The first vertebroplasty case report appeared in an obscure low-Impact Factor (0.8) journal, from a team who subsequently published dozens of articles but never a trial. ${ }^{2}$ Since 1987, although thousands of articles have been published, it is exceptional to find an adequately designed trial (eg, blinded, compared with a sham procedure, adequate number of patients, large patient cohorts, long clinical follow-up using relevant outcomes such as patients' quality of life). In 2016, the Vertebroplasty for Acute Painful Osteoporotic Fractures (VAPOUR) trial showed improved pain relief but with an absurdly short 14-day followup. ${ }^{3}$ The most recent trial on vertebroplasty showed robust evidence that it did not result in benefit for patients with acute osteoporotic vertebral compression fractures. ${ }^{4}$

Sadly, health care systems are resistant to learning from error. The 2009 Angioplasty and Stenting for Renal Artery Lesions (ASTRAL) trial showed that dilation and stent placement in renal arteries provided no benefit over drug treatments but only increased serious harm. However, the procedure had spread like wildfire since the 1980 s with 45,000 procedures annually in the United States. ${ }^{5}$ Surgeons and radiologists are not alone because the issue also concerns medicines. Encainide and flecainide have long been the standard of care after myocardial infarction to suppress ventricular premature complexes, until the Cardiac Arrhythmia Suppression Trial (CAST) investigators showed it increased mortality. ${ }^{6}$ Presently, most approvals of anticancer medicines are based on flimsy or untested surrogate end points, and most drugs offer marginal benefits that may be lost in the real world of heterogeneous patients in whom only harms appear. ${ }^{7}$

The solution is a challenge. In 1660, Pascal warned, "People almost invariably arrive at their beliefs not on the basis of proof but on the basis of what they find attractive" (The Art of Persuasion).

Pragmatically, Chandra et $\mathrm{al}^{1}$ should have pledged that all new patients be included in randomized controlled trials and, if that were not possible, in registries for monitoring adverse effects.

At the system level, training in history and humility should be an integral part of the medical curriculum. Editors must restrain researchers with preliminary observations from "sciensationalism" (sensationalism in science). ${ }^{8}$ Terms such as "therapeutic revolution" should be unacceptable. ${ }^{9}$ Professional societies must scrutinize their recommendations and grade them according to the evidence.

Disclosures: Susan Bewley — UNRELATED: Chair of HealthWatch, a charity that stands for better understanding by the public and the media of the importance of application of evidence from robust clinical trials (https://www.healthwatch-uk.org/).

\section{REFERENCES}

1. Chandra RV, Maingard J, Asadi H, et al. Vertebroplasty and kyphoplasty for osteoporotic vertebral fractures: what are the latest data? AJNR Am J Neuroradiol 2018;39:798-806 CrossRef Medline

2. Galibert P, Deramond H, Rosat P, et al. Preliminary note on the treatment of vertebral angioma by percutaneous acrylic vertebroplasty [in French]. Neurochirurgie 1987;33:166-68 Medline

3. Clark W, Bird P, Gonski P, et al. Safety and efficacy of vertebroplasty for acute painful osteoporotic fractures (VAPOUR): a multicentre, randomised, double-blind, placebo controlled trial. Lancet 2016;388: 1408-16 CrossRef Medline

4. Firanescu CE, de Vries J, Lodder P, et al. Vertebroplasty versus sham procedure for painful acute osteoporotic vertebral compression fractures (VERTOS IV): randomised sham controlled clinical trial. BMJ 2018;361:k1551 CrossRef Medline

5. Wheatley K, Ives N, Gray R, et al; ASTRAL Investigators. Revascularization versus medical therapy for renal-artery stenosis. N Engl JMed 2009;361:1953-62 CrossRef Medline

6. Greene HL, Roden DM, Katz RJ, et al. The Cardiac Arrhythmia Suppression Trial: first CAST . . . then CAST-II. J Am Coll Cardiol 1992; 19:894-98 CrossRef Medline

7. Kim C, Prasad V. Strength of validation for surrogate end points used in the US Food and Drug Administration's approval of oncology drugs. Mayo Clin Proc 2016 May 10. [Epub ahead of print] CrossRef Medline

8. Braillon A. Sciensationalism. Am J Med 2011;124:e13 CrossRef Medline

9. Braillon A. Direct-acting antiviral drugs and hepatitis C virus: a therapeutic revolution? Cancer 2015;121:4268-69 CrossRef Medline

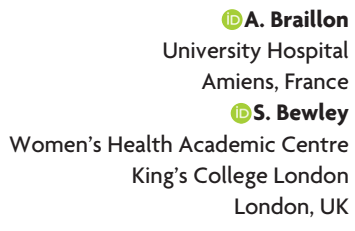

(1)A. Braillon niversity Hospital Amiens, France S. Bewley London, UK

http://dx.doi.org/10.3174/ajnr.A5762 